\title{
Milton's Bower of Bliss: A Rewriting of Spenser's Art of Married Love
}

\author{
JOHN N. KING
}

Spenser's Bower of Bliss episode functions as a mock epithalamium that inverts the state of wedded bliss celebrated in Amoretti and Epithalamion. ${ }^{1}$ The Bower's ironic portrayal of the entrapments of erotic love are reversed, as C. S. Lewis argues, ${ }^{2}$ in the cosmic vision of sexual pleasure at the Garden of Adonis, as well as at the "matrimoniall bowre" where the chaste love of Britomart and Artegall is destined to achieve fruition (3.3.3). The Bower of Bliss is a parody, not in the modern sense of a literary imitation designed to make an original appear comical or ridiculous, but in line with the medieval and Renaissance sense of a composition that seriously transfers conventions from one genre to another. This mock epithalamium denigrates the failures of Acrasia rather than the ideals of wedded love that Spenser articulates seriously elsewhere in his verse. ${ }^{3}$ Spenser's distinctively Protestant emphasis on the innocence of wedded love may be traced in the prayer book as well as in the sermons and tracts of zealous ministers. The Protestant doctrine of chaste love also found favor with Milton, who discovered a poetic mentor in "our sage and serious poet Spencer." When Milton came to reconfigure the ironies of the Bower of Bliss in the "blissful Bower" where Adam and Eve enjoy the fruits of prelapsarian love, he restored to full vitality the doctrine of chaste love that Spenser parodies in the seductive arbors and groves of Acrasia. ${ }^{4}$

Among the more obvious epithalamic parodies in the Bower of Bliss are the "Hymen iõ Hymen" refrain that was sung previously as an accompaniment to the False Una's tempting of the Redcrosse Knight (1.1.48), as well as the likeness of Acrasia's garden of delights to a bride decorated superfluously

With all the ornaments of Floraes pride,

Wherewith her mother Art, as halfe in scorne

Of niggard Nature, like a pompous bride

Did decke her, and too lavishly adorne,

When forth from virgin bowre she comes in th'early morne. $(2.12 .50)^{5}$ 
Other conventions of Renaissance pastoral and hexameral epithalamia that Spenser reverses or negates include the preparation of the nuptial chamber; praise of the bride, groom, wedlock, and the nuptial couch; the bashfulness of the bride; the congratulation of vernal Nature; consummation as a private and natural act; and the prayer for children. ${ }^{6}$ Because Acrasia is a variant of Venus Pandemos, whose power also flows into Malecasta and Duessa, we may recognize the Bower of Bliss as a perversion of the Bower of Venus that was traditionally associated with medieval gardens of love. ${ }^{7}$ Spenser's parodies and his continuous contrast of Art and Nature find a precedent in his immediate model, Armida's garden of love in Tasso's Gerusalemme Liberata, 16.1-27.

Having as little to do with virginity as Acrasia's innermost trysting place, her garden's lavishly parti-colored floral display contradicts the prayer book image of the ideal bride described in Epithalamion as "clad all in white, that seemes a virgin best" and walking "with trembling steps and humble reverence" $(11.151,210)$. Such outward modesty externalizes the virtuous beauty of the true bride's soul ("chastities sweet bowre"; 1. 180) through the imagery of a fruitful garden: apples, cherries, and lilies. The biblical models for pastoral epithalamium include the fertile gardens of Eden and Canticles, and Psalms, whose imagery of the fruitful vine, seedtime, and harvest infiltrates the English matrimonial ceremony. The governance of false Genius over the precincts of Acrasia ironically perverts the impulse toward procreation that marriage sanctified according to zealous Protestants like Spenser and Milton. The pure fecundity of wedlock is symbolized, on the other hand, by the tutelage of Spenser's "old Genius" over the Garden of Adonis (3.6.31) or "glad Genius" in Epithalamion (11. $398-400) .{ }^{8}$ Acrasia's delights similarly parody the joys of wedlock found in the "sweet pleasures of ... loves delight" in Epithalamion (1. 401), which are personified in Pleasure, Amoret's companion in the Garden of Adonis. Amoret's instruction in "all the lore of love, and goodly womanhead" (3.6.51) similarly furnishes a figure for the honesta voluptas of wedded love.9

The function of the Bower of Bliss as a place of single-minded sexual gratification inverts all of the purposes of marriage articulated in the prayer book - procreation, avoidance of fornication, and provision of "mutual society, help, and comfort" - aligning it instead with the simple satisfaction of "men's carnal lusts and appetites, like brute beasts that have no understanding." 10 These words from the wedding ceremony suggest that Verdant's enervation and Acrasia's transformation of her victims into "figures hideous, / According to their mindes like monstruous" (2.12.85) is not only a recreation of the classical myth of Circe, but also a parody of contemporary Protestant wedding ideals.

The very choice of the name "bower" for Acrasia's lair indicates that sexual gratification per se is not evil, but only if it is pursued to the exclusion of 
its religious and ethical purposes. Venus's Bower was a well-known figure for sanctified bliss among Protestant hexameral poets. ${ }^{11}$ The Protestant topos of use and abuse, found in the writings of Melanchthon, Cranmer, Vermigli, and others, ${ }^{12}$ whereby the possibility of misuse cannot negate the potentially good application of a given practice, further suggests that Acrasia's haunt parodies forms of true love associated with the bowers of honest women. Spenser generally reserves the word "bower" for idealized dwellings like Venus's "blisfull bowre of joy" (3.6.11) or inner chambers used as ladies' private apartments or bedrooms. ${ }^{13}$ Timias' perception of the chaste virgin Belphoebe as an angel sent from her heavenly "bowre of blis" (3.5.35) even links that setting with chaste love devoid of sexuality. The protection and enclosure of bowers are appropriate to the chaste modesty of true lovers, even though they can also conceal the furtive hypocrisy of others. Bowers may serve as places of lustful assignation, but they also provide meeting places for legitimate lovers. ${ }^{14}$ Placement of Acrasia's bower within a garden setting further evokes the shaded arbors offering places of concealment within Italian gardens, whose popularity was encouraged by the Arcadian vogue. ${ }^{15}$ Of course, the Bible and hexameral poets loom among Milton's models, but the anti-Eden of the Bower of Bliss (see 2.12.52) supplies much of the verbal texture of Milton's description of Adam and Eve's dwelling in Paradise.

Spenser characteristically assigns his alliterative doublet "blissful bower" or "bower of bliss," either literally or metaphorically, to places of honest sexual pleasure, as in descriptions of Venus's dwelling or the lady's bosom in Amoretti 76 ("the bower of blisse, the paradice of pleasure"). Prothalamion celebrates the pleasures of the "lovers blisfull bower" (1.93). ${ }^{16}$ Thomas Carew recognized the ironic character of the application of the epithet to Acrasia's Bower of Bliss in his ribald Spenserian parody "A Rapture," whose pornographic speaker proclaims his exultant carpe florem:

I'le seize the Rose-buds in their perfum'd bed,

Then will I visit, with a wandring kisse,

The vale of Lillies, and the Bower of blisse:

And where the beauteous Region doth divide

Into two milkie ways, my lips shall slide. $(11.63,67-70)$

Maureen Quilligan's discovery of a "gender-oriented stance" in The Faerie Queene suggests that Carew aptly captures Spenser's sense, for she interprets Guyon's "experience in the Bower of Bliss ... [as] a distinctly male version of the pornographic lure of the labyrinth's leisure." Whether Carew's speaker adopts Spenser's parodic perspective is a different question. ${ }^{17}$

Milton reverses the meretricious associations that Carew rightly discovers in Acrasia's Bower of Bliss when he attaches the epithets "blissful 
bower" and "shady bower" to the "sylvan lodge" (4. 690 and 705, 5. 367, 375-77) where Adam and Eve enjoy chaste intercourse in the Garden of Eden:

Here in close recess

With flowers, garlands, and sweet-smelling herbs

Espoused Eve decked first her nuptial bed,

And heavenly choirs the hymenean sung.(PL, 4. 708-11)

By eradicating the ironies of the Bower of Bliss, Milton restores to full vitality the doctrine of love that Spenser parodies in the languid pleasuregardens destroyed by Guyon and the Palmer. Praise of the wedding couch is, of course, a serious topic among the hexameral poets. Eve's decking of the matrimonial bed with floral coverings rather than textiles corresponds to the moral "costume" worn by Adam and Eve, who are, despite their nudity, "with native honour clad/In naked majesty" and "in naked beauty more adorned" (4. 289-90 and 713). When Adam and Eve retire for the night, their nudity

... eased the putting off

These troublesome disguises which we wear. (4.739-40)

Although nudity is a formulaic element in both the Bower of Bliss and Milton's Edenic bower, the absence of clothing can be applied as an emblem for either the presence or absence of virtue. Indeed the postlapsarian wantonness of Acrasia's exposure corresponds not to the Garden of Adonis, but to Adam and Eve's unconcealed lustfulness after the Fall. Like the hexameral poets, Spenser insists on the natural privacy of consummation in "the thickest covert of that shade" at the center of the Garden of Adonis (3.6.44). In a seeming paradox, however, Acrasia's nakedness within her bower is enhanced by the false modesty of her being

All in a vele of silke and silver thin,

That hid no whit her alabaster skin (2.12.77)

Yet Panofsky demonstrates that even though nakedness signified "either poverty, or shamelessness" in Hebrew and late Roman iconography, during the Renaissance "nudity as such, especially when contrasted with its opposite, came to be understood as a symbol for truth in a general philosophical sense."18

Acrasia's wanton shamelessness is a variation of the provocative carpe florem song audible in her bower, which imitates Gerusalemme Liberata 16.14-15: 
So passeth, in the passing of a day,

Of mortall life the leafe, the bud, the flowre,

Ne more doth flourish after first decay,

That erst was sought to decke both bed and bowre,

Of many a Ladie, and many a Paramowre:

Gather therefore the Rose, whilest yet is prime,

For soone comes age, that will her pride deflowre:

Gather the Rose of love, whilest yet is time,

Whilest loving thou mayst loved be with equall crime. (2.12.75)

Lacking in such artifice, Eve, on the other hand, is identified with unplucked roses before the expulsion from Eden: "Her self, though fairest unsupported flower" (9.432). ${ }^{19}$

While Milton does not simply "copy" a literary source, his reconfiguration of many Spenserian elements (the garden setting, lovers' bower, nudity, and bed of roses), some of which are shared in common with hexameral poets such as Du Bartas, Andrew Ramsey, and Jacob Cats, ${ }^{20}$ suggests that he styles the prelapsarian bliss of Adam and Eve along the lines of the literary model of the Bower of Bliss at the same time that he interprets that Spenserian setting as an ironic perversion of lost innocence. This patterning extends to the common use of key words to describe the "decking" of the Acrasian and Miltonic bower beds and the "veiling" of true and false women who embody related ideals of feminine beauty. The rewriting of the Bower of Bliss in the Garden of Eden suggests that Milton is not a slavish imitator, but a thorough-going interpreter and critic of his Spenserian prototype.

Although Adam and Eve are completely innocent in the prelapsarian exposure of their bodies, their night-time sharing of a floral blanket corrects the lewdness of Acrasia's posture "upon a bed of Roses" (2.12.77):

And on their naked limbs the flowery roof

Showered roses, which the morn repaired. (4. 772-73)

The decorum of blooming and regeneration in the garden, where "not nice art / In beds and curious knots, but nature boon / Poured forth" (4. 241-43), reverses the artificial and profligate flowering of the Bower of Bliss.

Adam and Eve's open display of "those mysterious parts" (4.312) reinforces the narrator's celebration of "the rites / Mysterious of connubial love" (4.742-43) in language echoing St. Paul's view of marital relations as a symbol for the union with Christ of every believer: "This mystery is a profound one, and I am saying that it refers to Christ and the church" (Eph. 5:32). While "naked" Adam's shoulder-length hair furnishes no concealment, Eve is characteristically "veiled" in ways that suggest a modest spirit while her loins remain exposed. Her golden hair falls "as a veil down to the 
slender waist” (4. 304-305). Possibly Milton “cut short Eve's hair" in order to leave the lower part of her body unconcealed. ${ }^{21}$ When she and Adam embrace,

... her swelling breast

Naked met his under the flowering gold

Of her loose tresses hid. (4. 495-97)

As Eve works among the flowering plants, she is "Veiled in a cloud of fragrance" (9.425). Unlike the bower that she "decked" with flowers, even in her meeting with the outsider Raphael, Eve stands

Undecked, save with herself more lovely fair

Than wood-nymph, or the fairest goddess feigned

Of three that Mount Ida naked strove,

Stood to entertain her guest from heaven; no veil

She needed, virtue-proof, no thought infirm

Altered her cheek. (5. 380-85)

A textile veil would be superfluous to one so clad "with native honour."

The "veiling" of Eve reverses the pervasive veiling characteristic of Acrasia's Bower of Bliss as a whole, just as Verdant's removal of his "warlike armes" (2.12.80) provides a postlapsarian analogue to Adam's nakedness. Spenser models Acrasia's filmy veil on il vel that leaves Armida's bosom exposed just as he finds the antithesis to Christian heroism in the indecency of Rinaldo's exposure in Gerusalemme Liberata (16.18-20, 27). Annette Dauber notes that the "Bower achieves its most characteristic effects by the use of veils." Genius is daintily "deckt" with flowers that flimsily conceal him like the floral display with which Art did "decke" her daughter Flora, the personification of the pleasure-gardens (sts. 49-50). Imagery of veiling proliferates at the center of the gardens near the Bower itself according to Dauber, for "nearly everything is seen through something else." 22 The reader perceives the fountain, its relief of "naked boyes," and the golden ivy overgrowing it through the "silver flood." Bathing in the "little lake" are two "naked Damzelles," whose lascivious display "as through a [watery] vele" prefigures Acrasia's exposure: "both awhile would covered remaine... / Then suddeinly both would themselves unhele, / And th'amarous sweet spoiles to greedy eyes revele" (sts. 60-64). ${ }^{23}$ The "subtile net" (2.12.81) with which Guyon and the Palmer trap Acrasia reduplicates her "vele of silke and silver thin":

More subtile web Arachne cannot spin,

Nor the fine nets, which oft we woven see

Of scorched deaw, do not in th'aire more lightly flee. (st. 77) 
Even though Acrasia wears veils within veils, Dauber notes that they enhance rather than detract from the laying bare of her "snowy brest ... to readie spoyle / Of hungry eies" (st. 78), for she is "draped in thin silk, glistening with sweat, [and has] eyes filmed with moisture" (p. 168). Her attire is that of a courtesan whose filmy garments incite desire by concealing nothing.

Spenser and Milton are writing "myths about love in a fallen world" according to Thomas Roche: "The pattern is the same: Eden - the Fall love in marriage." Spenser insists that the only means of recovering even "the vestiges of our pre-Fall Eden" is through unions effected by love between husband and wife, friends, or rivers. ${ }^{24}$ The innocent bower of Adam and Eve no longer exists, for its closest approximation is their place of lustful embracing immediately after the Fall:

\section{... to a shady bank,}

Thick overhead with verdant roof embowered

He led her nothing loth; flowers were the couch,

Pansies, and violets, and asphodel,

And hyacinth, earth's freshest softest lap. (9. 1037-41).

In this ironic epithalamium, ${ }^{25}$ the floral bed and "verdant roof embowered" evoke both Milton's "blissful bower" and its postlapsarian corollary of the Bower of Bliss, where Spenser's allegorical mode dictates that Verdant function as a personification rather than a color. In describing Adam and Eve, who now share the clouded reason of Acrasia and her sleeping companion, Milton's description of the nakedness of the once-innocent pair reiterates the "veil," "honour," and "virtue" once associated with "that first naked glory" (9.1115):

\section{... innocence, that as a veil}

Had shadowed them from knowing ill, was gone,

Just confidence, and native righteousness

And honour from about them, naked left

To guilty shame he covered, but his robe

Uncovered more, so rose the Danite strong

Herculean Samson from the harlot-lap

Of Philistean Dalilah, and waked

Shorn of his strength, they destitute and bare

Of all their virtue. $(9.1054-63)^{26}$

In line with the distinctly idolatrous transformation of the "mystery of divine love" that Stephen Greenblatt discovers in the Bower of Bliss, the "uncanny parody of the Pietà suggested by Verdant cradled in Acrasia's arms" extends into Milton's portrayal of Eve. Milton's reconfiguration of 
traditional Catholic iconography associates postlapsarian lust with "evils attributed to the misuse of religious images." 27 Although both Eve and Mary lack Acrasia's sinister maternality, they are twice compared when Raphael addresses to Eve "the holy salutation used / Long after to blest Marie, second Eve" (5.386-87), and then when Christ prophesies as the "son of Mary second Eve" (10.183). Because parody functions not only as a burlesque device, but also as a vehicle for seriously translating conventions from one genre or medium to another, we may note that rather than rejecting Marian iconography, Milton sanctions traditional imagery by returning it to its scriptural origins. Christ's scriptural prophecy to Satan that Eve's "seed shall bruise thy head, thou bruise his heel" (10.181) is of this kind, for trampling on a serpent or symbols of evil is one of the traditional roles of the Virgin Mary. Spenser's method similarly lacks irony when he applies to Queen Elizabeth, rather than Eve, iconography once assigned to the Blessed Virgin, such as the Coronation of the Virgin. The conflation of Eve's image with that of Venus in late medieval and Renaissance iconography suggests that Acrasia as a variant of Venus Pandemos may be as much a model for Milton's Eve, both before and after the Fall, as Venus and Eve are for the Virgin Mary during the Middle Ages. ${ }^{28}$ The tradition of Venus's Bower lies behind the Garden of Adonis and Milton's Eden, as well as the Bower of Bliss. The principle of literary parody provides for the malleable transformation of images, and their inversions, into positive or negative manifestations without necessarily reflecting against either prototypes or their posterity. ${ }^{29}$

The realization that Milton's "bower as a whole is an emblem of true married love" represents, for Alastair Fowler, an extension of the epithet "costliest emblem" (note on 4. 700-703), which describes the inlaid floral ornamentation associated with Adam and Eve's "nuptial bed" (4.700-711). Certainly the alternate sense of "pictorial symbol" that Fowler discovers in "emblem" is present as well, and thus the bower's "seclusion and concealment... reflect the privacy and particular belonging of the marital relation." Such natural modesty is a conventional attribute of the marital relationship for the Protestant hexameral poets and Milton. The "rites / Mysterious of connubial love" shared by the first parents further reflect the spiritual mystery of Christ's union with the Church that St. Paul locates in the matrimonial relationship (Eph. 5:31-33). This favourite Protestant authority states: "Let marriage be held in honor among all, and let the marriage bed be undefiled" (Heb. 13:4).

The artful praise of the bowers of chaste lovers that Milton shares with Spenser reaffirms the purity of married love articulated by English Protestants and the prayer book. ${ }^{30}$ Spenser's rewriting of the Bower of Bliss in the Garden of Adonis, with its "pleasant arbour, not by art, / But of the trees owne inclination made" (3.6.44), constitutes the primary statement of 
marital ideals in The Faerie Queene. Similarly Milton's reversal of the imagery of Acrasia's gardens indicates that Spenser's anti-Eden joins the Bible and hexameral poets as a major literary model for the "bower" of Adam and Eve. Although many of the poets' similarities stem from their application of a common literary and moral tradition, the thick accumulation of Milton's parallels and his reiteration of key terms from The Faerie Queene - "blissful bower" and "decked" - make virtually certain his debt to the epic poet of Tudor England. Such practice would bear out the homage paid by Milton in Areopagitica to "our sage and serious Poet Spencer, whom I dare be known to think a better teacher than Scotus or Aquinas." Surely Milton absorbs the Spenserian position that the Protestant doctrine of the sanctity of wedded love corrects the celibate ideal affirmed by the Church of Rome. Spenser's conception of chastity had been molded by "the strong hostility to the old Catholic scheme of virtues in Protestant polemic." Almost in the same breath with which he describes Spenser as "sage and serious," 31 Milton singles out for praise his mentor's doctrine of "true temperance" as he exemplifies it in "the bowr of earthly blisse that he [Guyon] might see and know, and yet abstain." 32 Milton's hostility to the chastity of medieval monks and clerics, whose virtue was "fugitive and cloistered,"33 is conditioned by Spenser's redefinitions of chastity in the Epithalamion, Book Three of The Faerie Queene, and the Bower of Bliss episode.

\section{Bates College}

Notes

1 I am grateful to Thomas Kranidas for suggesting that I write this essay. A shortened version was delivered at the session on Spenser and Milton at the 1985 meeting of the Modern Language Association. Quotations follow The Faerie Queene, ed. A. C. Hamilton (London: Longman, 1977); Spenser's Minor Poems, ed. Ernest de Sélincourt (Oxford: Clarendon Press, 1910); and Paradise Lost, rev. ed. by Alastair Fowler (London: Longman, 1971). The modern use of $\mathrm{i}$ and $\mathrm{j}, \mathrm{u}$ and $\mathrm{v}$, and $\mathrm{vv}$ is followed; contractions are expanded.

2 The Allegory of Love: A Study in Medieval Tradition (Oxford: Clarendon Press, 1936), pp. 32526.

3 On the related usage of secular music in religious poetry, see Rosemond Tuve, "Sacred 'Parody' of Love Poetry, and Herbert," Studies in the Renaissance, 8 (1961), 250-51, 254-55. Hallett Smith demonstrates how epithalamic conventions may be applied both positively and negatively in affirmation of the same ideals of matrimonial sanctity in "The Use of Conventions in Spenser's Minor Poems," ed. William Nelson in Form and Convention in the Poetry of Edmund Spenser: Selected Papers from the English Institute (New York: Columbia University Press, 1961), pp. 136-44.

4 In The Figure of Echo: A Mode of Allusion in Milton and After (Berkeley and Los Angeles: University of California Press, 1981), p. 84, John Hollander notes that it "is this Spenserian inversion of the name of the false inversion of the place of love - which Milton echoes in Paradise Lost, Book IV.... [It resounds] against the inversion already present in Spenser's own selfechoing." After the present article had gone to press, I became aware of Barbara K. Lewalski's observation in "Paradise Lost" and the Rhetoric of Literary Forms (Princeton: Princeton University Press, 1985) that Satan, as a "perverse Guyon ... detroys in Eden not a wantonly sinful but a joyously innocent Bower of Bliss and Love" (p. 71). 
5 The allusion to Flora works two ways, for this Roman flower-goddess is also famous for harlotry. E. K. interprets her in his gloss on The Shepheardes Calender, "March," 1. 16, as "the Goddesse of flowres, but indede (as saith Tacitus) a famous harlot, which with the abuse of her body having gotten great riches, made the people of Rome her heyre." See also Faerie Queene, $1.1 .48 \mathrm{n}$.

6 Gary M. McCown, "Milton and the Epic Epithalamium," Milton Studies, 5 (1973), 44-45, 50-55.

7 A. Bartlett Giamatti, The Earthly Paradise and the Renaissance Epic (Princeton: Princeton University Press, 1966), pp. 50-52. See also Joan L. Klein's identification of these "demonic" females, who also include Lucifera and Phaedria, as variants of Errour in "From Errour to Acrasia," Huntington Library Quarterly, 41 (1978), 173-99. On the symbolism of the "Venere Celeste" and "Venere Volgare," see Erwin Panofsky, Studies in Iconology: Humanistic Themes in the Art of the Renaissance (New York: Oxford University Press, 1939), pp. 152 and 160. On Spenser's twin Venuses see Lewis, Allegory of Love, pp. 331-32; and Thomas P. Roche, Jr., The Kindly Flame: A Study of the Third and Fourth Books of Spenser's "Faerie Queene" (Princeton: Princeton University Press, 1964), pp. 101-103.

$8 \mathrm{C}$. S. Lewis outlines the varied meanings of Genius, who originally served the Romans as the tutelary deity of every individual, in Allegory of Love, pp. 361-63.

9 Roche, Kindly Flame, pp. 126-28.

10 The Book of Common Prayer 1559: The Elizabethan Prayer Book, ed. John E. Booty (Charlottesville: University Press of Virginia for the Folger Shakespeare Library, 1976), p. 290-91.

11 Giamatti notes in The Earthly Paradise that "the fact that Claudian's description coincided with the Christian versions of the earthly paradise behind or upon a mountain meant he could safely be read as a secular (and pleasurable) analogue to what was religiously acceptable" (p. 50, n. 52).

12 Melanchthon on Christian Doctrine: "Loci Communes 1555", tr. and ed. Clyde L. Manschreck (New York: Oxford University Press, 1965), pp. 306-16; and Pietro Martire Vermigli, Common Places, tr. and partly gathered by A. Marten (1583), Pt. 2, sigs. $2 \mathrm{L1}^{\mathrm{r}-\mathrm{v}}, 2 \mathrm{~L} 4^{\mathrm{v}}-5^{\mathrm{v}}, 2 \mathrm{M}^{\mathrm{r}}-2^{\mathrm{v}}$, and 2M6r. See John Phillips, The Reformation of Images: Destruction of Ant in England, 1535-1660 (Berkeley and Los Angeles: University of California Press, 1973), pp. 48-63, passim.

13 OED, "Bower," $1 \mathrm{~b}$ and $2 \mathrm{~b}$.

14 See Shepheardes Calender, “August," 1. 167; Faerie Queene, 4.8.59; Amoretti 4; and esp. the "bridale bowre and geniall bed" of Epithalamion, 1. 399.

15 Roland Mushat Frye, Milton's Imagery and the Visual Arts: Iconographic Tradition in the Epic Poems (Princeton: Princeton University Press, 1978), p. 225. See also OED, "Bower," 3.

16 See Amoretti 78 and Prothalamion, 1. 93. Note that it is the married relationship in which "spotlesse pleasure builds her sacred bowre" (Amoretti 65). But compare Faerie Queene, 2.5.27, 2.12. Argument, 2.12.42, and 2.12.69.

17 Milton's Spenser: The Politics of Reading (Ithaca: Cornell University Press, 1983), pp. 187-88. In The Figure of Echo, pp. 83-85, John Hollander suggests that the "Bower of Bliss ... becomes a true earthly paradise, a legitimate if momentary fallen replacement of a lost unity of nature and man, when the words of its name are reversed in order." He argues that "Carew's echo is an outright denial of the meaning of the original voice."

18 Studies in Iconology, pp. 155 and 159. See Frye, Milton's Imagery, p. 263.

19 Frye, Milton's Imagery, p. 278-79.

20 McCown,"Milton and the Epic Epithalamium,"pp.44-46 and 49-50; see Giamatti, The Earthly Paradise, pp. 50-52.

21 Frye, Milton's Imagery, p. 273.

22 "The Art of Veiling in the Bower of Bliss," Spenser Studies, 1 (1980), 163-64, 168. On the conventionality of the veil in Boccaccio and Chaucer, see The Works of Edmund Spenser: A Variorum Edition, ed. E. A. Greenlaw, et al., 10 vols. in 11 (Baltimore: Johns Hopkins Press, 1932-57), II, $391-92$.

23 Spenser adapts to his allegorical scheme the "veiling" of one of Tasso's naked damsels by a lake in Gerusalemme Liberata, 15.59: "E '1 lago all' altre membra era un bel velo."

24 Kindly Flame, p. 178.

25 McCown, "Milton and the Epic Epithalamium," p. 59. 
26 Note also Christ's clothing of Adam and Eve ... with the skins

Of beasts, but inward nakedness, much more

Opprobrious, with his robe of righteousness,

Arraying covered from his Father's sight. (10. 220-23)

27 Renaissance Self-Fashioning: From More to Shakespeare (Chicago: University of Chicago Press, 1980), pp. 188-89.

28 Frye, Milton's Imagery, pp. 276-77. Note the slatternly posture of Venus, as a prototype for Eve, in Illus. 208.

29 In Spenser's "Faerie Queene" and the Cult of Elizabeth (London: Croom Helm, 1983), Robin H. Wells notes the survival of Catholic images of the Virgin Mary in The Faerie Queene. Spenser applies to married love Protestant parodies of values associated with the celibate ideal in Catholic iconography, as in his revision of the "Hail Mary" in the Anacreonic coda to Amoretti:

I saw in secret to my Dame,

How little Cupid humbly came:

and sayd to her All hayle my mother. (st. 3)

Milton avoids classical imagery, on the other hand, when he corrects the "Hail Mary" by returning it to what he assumes are its origins in Genesis when Raphael extends to Eve the greeting: "Hail mother of mankind, whose fruitful womb / Shall fill the world more numerous with thy sons" (PL, 5. 388-89). This redefinition of medieval iconography of the Blessed Virgin, which would have seemed blasphemous to Catholics, is part of the ongoing effort of both Spenser and Milton to transform or assimilate Roman Catholic imagery into thoroughly Protestant patterns of thought. Spenser's Protestantism permeates his reapplication of the cosmic implications of Mary's experience when he transfers traditional iconography to many of the idealized women of The Faerie Queene. See John N. King, "The Godly Woman in Elizabethan Iconography," Renaissance Quarterly, 38 (1985), 81-83.

30 Many literary historians have reductively termed the idealization of married love in Spenser and Milton a "Puritan" rather than a fundamentally Protestant phenomenon. See William and Malleville Haller, "The Puritan Art of Love," Huntington Library Quarterly, 5 (1942), 23572; William Haller, " 'Hail Wedded Love,' "ELH, 13 (1946), 79-97; Roland Mushat Frye, "The Teachings of Classical Puritanism on Love in Marriage," Studies in the Renaissance, 2 (1955), 148-59; and John Halkett, Milton and the Idea of Matrimony: A Study of the Divorce Tracts and "Paradise Lost" (New Haven: Yale University Press, 1970). For a qualification of this view, see John N. King, English Reformation Literature: The Tudor Origins of the Protestant Tradition (Princeton: Princeton University Press, 1982), pp. 281-82,307. McCown associates Renaissance pastoral and epic epithalamia with the Protestant praise of matrimony in "Milton and the Epic Epithalamium," p. 56. See also Peter Lindenbaum, "Lovemaking in Milton's Paradise," Milton Studies, 6 (1974), 277-306.

31 In Poetry and Politics in the English Renaissance (London: Routledge and Kegan Paul, 1984), p. 251 , David Norbrook notes that "sage and serious" are the adjectives with which the Lady praises the "doctrine of virginity." See Comus, 11. 785-86, in Complete Shorter Poems, rev. ed. John Carey (London: Longman, 1971).

32 Complete Prose Works, ed. Don M. Wolfe et al., 8 vols. in 10 (New Haven: Yale University Press 1953-82), II, 516.

33 Norbrook notes in Poetry and Politics, p. 251, related examples of Protestant attacks on celibacy and redefinitions of chastity in the writings of John Bale and Andrew Marvell. 